\title{
The Difference of Students Mathematical Problem Solving Ability and Self Regulated Learning Taught Contextual and Cooperative Learning Models
}

\author{
Meytri Laurence Sihotang \\ State Universityof Medan \\ Medan, Indonesia \\ Corresponding email: sihotangm33@yahoo.com
}

\author{
Mulyono, Ani Minarni, Else Frine Tamba \\ State Universityof Medan \\ Medan, Indonesia
}

\begin{abstract}
This study aims to analyze wether (1) there is a difference in students' mathematical problem solving abilities and self regulation learning (SRL) taught contextual learning models with students taught cooperative learning models geogebra assisted; (2) there is an interaction between learning models with early mathematical abilities of students mathematical problem solving abilities and SRL. This research is a quasi experimental study. The population is the all of students of Santo Yoseph Private Middle School Medan grade VIII. The instruments used in this study are test mathematic problem solving abilities and questionnaire for SRL. The results of the study are there is difference in students mathematic problem solving abilities and SRL taught through geogebra assisted contextual learning models with students taught through geogebra assisted cooperative learning models and there is an interaction between learning and students' initial mathematical abilities towards students mathematical problem solving abilities and SRL.
\end{abstract}

Keywords- Problem Solving, Self-Regulated Learning (SRL), Contextual Learning, Cooperative Learning, Geogebra

\section{INTRODUCTION}

Problem solving is an ability or skill very important be acquired, because from birth humans have faced challenging problems that forced him get the solution [12]. Solving problem either within mathematics or beyond is one of the ultimate goal students learn mathematics. It is since mathematics takes role tool as well as vehicle to develop problem solving ability [13]. Problem solving is very important because in the learning process and student completion is possible to gain experience using the knowledge and skills already possessed to be applied to problem solving [5].

While Uno [5], say that problem solving is answering the question which it need a method to find the solution from unknown question before. Students' mathematical problem solving ability can be defined as students' ability to understand problems, plan problem solving strategies, carry out selected strategies of resolution, and re-examine solving these problems to subsequently make solutions in a systematic and inseparable way with proper representation of the problem [18].
In mathematics learning, using problem solving strategies has an impact on students' ability and skills. Problem solving is viewed as an important part of understanding and learning in Mathematics, and emphasis increasingly is being placed upon improving problem solving abilities in mathematics. It is therefore important to investigate ways for improving problem solving skills [16]. The results of the study show that the problem solving approach affects the ability and academic achievement of students [30]; [34]; [22]; [29]; [25]; [33]; [17]; [26]; [28].

Polya [18] said there are four steps in solving the problem, namely: (1) understand the problem: in this activity is to formulate: what is known, what is asked, whether the information sufficient, condition (condition of) what should met, restate the original problem in a more operational (solvable). (2) planning the solution: the activities carried out in this step is trying to find or recall issues you've solved that has similarities with the properties that will be solved, look for patterns or rules, draw up resolution procedures. (3) implement the plan: the activities in this step are performs the procedures that have been created in the previous step to the settlement. (4) to re-examine the procedures and results of the settlement: activities in this step is analyzing and evaluating whether the procedures applied and the results obtained are correct, whether there are other procedures that are more effective, whether procedures have created can be used to solve similar problems, or whether the procedures generalizations can be made.

The indicators of mathematical problem solving ability in this study are; 1) Understanding, which is whether important information and ideas in the problem are known, 2) Representations, namely whether they have been able to make external representations of problems that make it easier for them to handle them, 3) Settlement, namely whether the strategy is chosen and the results are correct, 4) Conclude the results / solutions according to the initial problem.

But in fact this time is the problem solving ability of students in mathematics learning is low and needs to be improved, based on research results [4] students is low based on the analysis of student test results on the materials of opportunity". 
Likewise with Ibrahim's research [31] said that "Mathematics problems are really difficult. I did not know how to do it. That's why I did not finish it. I don't like Maths. These statements are quite familiarly heard when students are inquired about their homework. They seem to be struggling with their homework especially on mathematics problemsolving. Mathematics problem solving is not a topic but a process underlie the whole mathematics programmes which contextually helped concepts and skills to be learned".

Self-regulation is important because a major function of education is the development of lifelong learning skills [35]. The need for regulating one's own learning has emerged due to the value placed on education and it has underlined selfregulated learning. But the research into the issue has shown that low-achieving students have poor perception of their selfefficacy and that they use fewer learning strategies [1].

Academic motivation is considered as a powerful factor for students in terms of doing their homework and making them more interested in learning. This concept represents the difference of student's effort for doing their homework. Hence it is recognized as a significant factor in teaching and training [10]. Curently, the study of what self-regulated learning is, what processes are involved in it, and how to teach them, has become a burning topic within educational psychology and one of the principal directions where discipline is advancing [14]. Self-regulated learning skills are important in mathematical problem solving. The aim of the Marchis's paper is to present a research on how mathematics teachers guide their pupils' mathematical problem-solving activities in order to increase self-regulation [11].

Self-regulation is not a mental ability or an academic performance skill; rather it is the selfdirective process by which learners transform their mental abilities into academic skills [35]. Self-regulation is the control that students have over their cognition, behavior, emotions and motivation through the use of personal strategies to achieve the goals they have established [15]. Self-regulated "an active, constructive process whereby learners set goals for their learning and then attempt to monitor, regulate, and control their cognition, motivation, and behavior, guided and constrained by their goals and the contextual features in the environment "Pintrich [24]. Zimmerman [14] said what characterizes self regulating students is their active participation in learning from the metacognitive, motivational, and behavioral point of view.

Schunk \& Zimmerman [35] Said The component skills include: (a) setting specific proximal goals for oneself, (b) adopting powerful strategies for attaining the goals, (c) monitoring one's performance selectively for signs of progress, (d) restructuring one's physical and social context to make it compatible with one's goals, (e) managing one's time use efficiently, (f) self-evaluating one's methods, (g) attributing causation to results, and (h) adapting future methods. A students' level of learning has been found to vary based on the presence or absence of these key self-regulatory processes. The results of the study show that the self-regulated affects the ability and academic achievement of students [19].

Coming of ICT in education has brought many novelties and essentially changed its values, methods and results. That would be an important benefit for education system if the novelties and changes brought by ICT are accepted, used and developed by students, teachers, school administration, decision makers in local and state institutions and parents. With coming of ICT our attention should be paid to paradigm of modern pedagogy - student is in the centre of practical educational process, he can learn independently in suitable place, time and speed [3]; [9]; [27]; [23]; [20]; [21]. STEM (Science, Technology, Engineering and Mathematics) education aims to improve students' imagination and develop solutions to challenges by ways of applying their mathematical and scientific knowledge in technological design, problem-based learning, and authentic scientific inquiry [7].

Hohenwarter, Jarvis, \& Lavicza [23] said GeoGebra is free open-source dynamic software for mathematics teaching and learning that offers geometry and algebra features in a fully connected software environment. It was designed to combine features of dynamic geometry software (e.g. Cabri Geometry, Geometer's Sketchpad) and computer algebra systems (e.g.Derive, Maple) in a single, integrated, and easy to-use system for teaching and learning mathematics.

One of alternative so that mathematic lerning can be delivered concretely is by contextual learning. Contextual learning is a learning concept that helps the teacher to relate the learning material with the real world condition and support the students in making the knowledge they have with the application in their daily life [6]. An active learning environment with these characteristics it is possible to direct the students to be able to perform mathematics learning, which in turn students will have independent study mathematics [29].

Contextual learning is a learning concept that helps the teacher to relate the learning material she/he tought to studennt' real world condition and to support the students in making a relation between the kowledge they ve with the application in their daily life. Therefore, the conceptual learning prioritizes to the real world learning, high level learning, students central, student active, critical, creative, and solving the problem, joyfull quantum learning, and using many learning source [6]. Trianto [32] wrote these seven components, namely, constructivism, inquiry, questioning, learning community, modeling, authentic and authentic assessment. A class is said to apply a contextual learning model if applying the seven principles in learning.

Based on this, it is considered important for researchers to conduct research on the differences in problem solving skills and SRL of Saint Joseph Medan Catholic Private Middle School students using Geogebra assisted contextual learning models and cooperative learning models.

\section{RESEARCH METHOD}

This type of research is quasi-experimental. This study was conducted at the Santo Yoseph Medan Catholic Private Middle School which will be held in the odd semester of 2018/2019 academic year in class VIII with SPLDV material. The research instrument used the initial mathematical ability test, the mathematical problem solving ability test and the SRL questionnaire. The research design used in this study was 
posttest control group design. The purpose was given a posttest question to see differences in students mathematical problem solving ability. Data obtained from student grades will be grouped based on experimental class I (contextual) and experimental class II (cooperative). The statistical hypothesis test used was two-way ANOVA with a significance level of 0.05 .

\section{RESULT AND DISCUSSION}

After learning for each experimental class, the posttest results data are obtained as follows Table 1:

TABLE I. POSTtest Results DATA

\begin{tabular}{|c|c|c|c|c|c|c|c|c|}
\hline Aspect & \multicolumn{4}{|c|}{ Experiment Class I } & \multicolumn{3}{c|}{ Experiment Class II } \\
\hline & $x_{\min }$ & $x_{\text {maks }}$ & $\bar{x}$ & $\mathrm{~S}$ & $\begin{array}{c}x_{\mathrm{m}} \\
\text { in }\end{array}$ & $\begin{array}{c}x_{\mathrm{m}} \\
\mathrm{aks}\end{array}$ & $\bar{x}$ & $\mathrm{~S}$ \\
\hline $\begin{array}{c}\text { Understand } \\
\text { The Problem }\end{array}$ & 19 & 20 & 19,5 & $\begin{array}{c}0,70 \\
711\end{array}$ & 15 & 20 & $\begin{array}{c}17, \\
5\end{array}$ & $\begin{array}{c}3, \\
54\end{array}$ \\
\hline $\begin{array}{c}\text { Representati } \\
\text { on }\end{array}$ & 19 & 20 & 19,5 & $\begin{array}{c}0,70 \\
711\end{array}$ & 13 & 20 & $\begin{array}{c}16, \\
5\end{array}$ & $\begin{array}{c}4, \\
95\end{array}$ \\
\hline $\begin{array}{c}\text { Implement } \\
\text { The Plan }\end{array}$ & 8 & 19 & 13,5 & $\begin{array}{c}7,77 \\
817\end{array}$ & 8 & 20 & 14 & $\begin{array}{c}8, \\
49\end{array}$ \\
\hline $\begin{array}{c}\text { Conclude } \\
\text { The Results }\end{array}$ & 0 & 10 & 5 & $\begin{array}{c}7,07 \\
107\end{array}$ & 0 & 9 & 4,5 & $\begin{array}{c}6 \\
36\end{array}$ \\
\hline $\begin{array}{c}\text { Overall } \\
\text { Aspects }\end{array}$ & 48 & 69 & 58,5 & $\begin{array}{c}14,8 \\
492\end{array}$ & 49 & 65 & 57 & $\begin{array}{c}11 \\
, 3 \\
1\end{array}$ \\
\hline
\end{tabular}

After doing the research, the results of the mathematical problem solving ability of the experimental group 1 and experiment 2 students were 5.328 and a significant value of 0.024. Because the significant value is smaller than the significance level of 0.05 , it can be concluded that there are differences in students' mathematical problem solving ability obtained by the contextual learning model with students who are given a cooperative model. Furthermore, the results of SRL calculations in the experimental group I and experiment 2 were 1.306 and the significant value was 0.025 so it can be concluded that there were differences in SRL obtained by geogebra-assisted contextual learning models with students given a geogebra-assisted cooperative model.

The results of the two-way ANAVA test calculations to see the interaction between learning and early mathematical ability on mathematical problem solving ability of experimental groups I and II obtained a value of 3.424 and a significant value of 0.038 . Because the significant value is smaller than the significant level of 0.05 , it can be concluded that there is a significant interaction between the learning model and students 'initial mathematical ability on students' mathematical problem solving ability. This can be interpreted that there is a shared influence given by the learning model and initial mathematical abilities on students' mathematical problem solving ability. The results of the next calculation for SRL in the experimental group I and experiment II were 3.424 and a significant value of 0.038 . Because the significant value is smaller than the significant level of 0.05 , so that it can be concluded that there was a significant interaction between the learning model and students' initial mathematical ability towards SRL. This can be interpreted that there is a shared influence given by the learning model and initial mathematical abilities on SRL.

Cooperative learning model which is a teaching and learning strategy that emphasizes shared attitudes / behavior in working or helping among others in the structure of regular cooperation in groups, which consists of 2 or more people to solve the problems. Eggen and Kauchak said that cooperative learning is a group of teaching strategies that involve students working collaboratively to achieve common goals. The main idea of cooperative learning is that students work together to learn and are responsible for the learning progress of their friends. Because students work in a team, it can naturally improve relations between students from various ethnic backgrounds and abilities, develop group process skills and problem solving [32].

Learning theories underlying the cooperative learning model include constructivism learning theory, meaningful learning theory from Ausubel, and Vygotsky's theory of the importance of language society. A knowledge is the result of students' own construction which causes learning to be more meaningful. With the discussion and interaction with other students (peer tutoring) it will develop new strategies and techniques in solving each problem. This learning emphasizes the importance of assimilation of experience into cognitive structures and emphasizes that the learning process is by the way students are active.

Besides that, the contextual learning model is an approach that emphasizes the process of full student involvement to be able to find the material being studied and connect it to real life situations, thus encouraging students to be able to apply it in their lives. The contextual learning model assumes that naturally the mind searches for the meaning of the context in accordance with the real situation of one's environment through finding a reasonable and useful relationship. In the contextual approach the teacher's task is to provide ease of learning to students by providing various means and adequate learning resources. Teachers not only deliver lesson material in the form of memorization, but regulate the environment and learning strategies that allow students to learn.

The contextual learning model with its components is a learning model that is supported by many learning theories. The theory of constructivism, which emphasizes the importance of students constructing or contriving their own knowledge, Dewey's learning theories about the importance of asking and reflecting in learning. Piaget's theory of learning is very important for authentic assessment and learning by finding students' own knowledge during the learning process, Ausubel's learning theory that emphasizes the importance of meaningful learning, Bruner's learning theory [2] which also suggests the importance of learning discovery, Vygotsky's learning theory, Piaget and Bruner about the importance of group learning.

Based on the results of data analysis on the average posttest of both classes, classes taught through geogebra software assisted contextual learning models obtained a mean score of 86,769 and for classes taught through direct learning models assisted by geogebra software obtained a mean score of 81,089. This shows that there are differences in 
mathematical problem solving ability in the experimental class I and experimental class II.

Learning to associate the material with real situations of everyday contributed to the mathematical problem-solving ability and independence of student learning. The results of this study are reinforced by Yanti [34]; Rusyida, Asikin, and Soedjoko [22]; Surya, Sabandar, Kusumah, and Darhim [29]; Siagian, Saragih, and Sinaga [25]who say the achievement of problem solving abilities of students who get contextual learning (CTL) assisted by geogebra or ICT is better than expository learning. Problem solving ability not only can be achieved through CTL but also through problem basedlearning [12]. Just like problem-based learning, CTL is also a learning model that can make the students actively engage in solving problem because these two kind of learning is based on constructivism.

Based on the results of data analysis on the average score then calculated for differences in the two classes, classes taught through contextual learning models assisted by geogebra software obtained a mean of SRL score of 90,510 and for classes taught through cooperative learning models assisted by geogebra software obtained a mean score of 88,469 for SRL. Thus it shows that there is a difference in SRL between students who were given a contextual learning model with geogebra software (experimental class I) and students given a cooperative learning model with geogebra software (experimental class II). The results of this study are supported by previous studies namely Marchis [11]; Jumaisyaroh, Napitupulu, and Hasratuddin [8] who said that the SRL of the students increase with given contextual and ICT-based learning.

From the results of the analysis carried out on the learning model with 'initial mathematical abilities on students' mathematical problem solving ability indicate that there is interaction. The results of this study are in line with Surya, Sabandar, Kusumah, and Darhim [29]concluding that the CTL learning model can improve the ability of previous students at all levels of 'initial mathematical abilities (high, medium and low). The representation ability of students in all three groups significantly increased. Student who get high, medium, and low 'initial mathematical abilities increase significantly with CTL learning different from 'initial mathematical abilities in conventional conventional learning. In other words there is an interaction between learning and 'initial mathematical abilities (high, medium, and low) to improve student learning outcomes, namely students' problem solving ability.

\section{CONCLUSION}

Based on the results of data analysis and research results, it can be concluded that there are differences in mathematical problem solving abilities and SRL between students given contextual learning models and cooperative models assisted by geogebra software. Differences in mathematical problem solving abilities and SRL are caused by differences in learning used and also because of students' initial mathematical abilities. Thus it is expected that mathematics teachers can facilitate students' learning material that is associated with the real world as found in the syntax of the contextual learning model and integrate ICT in mathematics learning at school.

\section{REFERENCES}

[1] Altun, S. \& Erden, M., Self-Regulation Based Learning Strategies and Self-Efficacy Perceptions as Predictors of Male and Female Students' Mathematics Achievement. Procedia - Social and Behavioral Sciences, 106 ( 2013 ) 2354- 2364, 1877-0428, 2013.

[2] Bruner, J. S., The Act of Discovery. Harvard Educational Review, 3 (1), 21-32, 1961.

[3] Cunska, A. \& Inga, S, Use of ICT Teaching-Learning Methods Make School Math Blossom. Procedia - Social and Behavioral Sciences, 69 ( 2012 ), 1481-1488, 2012.

[4] Eviyanti, C.Y., Surya, E., Syahputra, E. \& Simbolon, M, 2017. Improving the Students' Mathematical Problem Solving Ability by Applying Problem Based Learning Model in VII Grade at SMPN 1 Banda Aceh Indonesia. International Journal of Novel Research in Education and Learning, 4(2), 138-144, 2017.

[5] Fuadi, I., Minarni, A., \& Banjarnahor, H., Analysis Of Students' Mathematical Problem Solving Ability In IX Grade At Junior High School Ar-Rahman Percut. International Journal of Novel Research in Education and Learning, 4(2), 153-159, 2017.

[6] Hasibuan, A.Z.O., Surya,E., \& Syahputra, E, The Application of CTL to Improve Students' Understanding Concept Ability by Matflash Graphic Media Assistance. IJARIIE-ISSN(O), 3(2), 3222-3230, 2017.

[7] Hassan, M.N., Abdullah, A.H., Ismail, N., Suhud, S.N.A., \& Hamzah, M.H., Mathematics Curriculum Framework for Early Childhood Education Based on Science, Technology, Engineering and Mathematics (STEM). Internasional Electronic Journal of Mathematics Education, 14(1), 15-31, 2019.

[8] Jumaisyaroh, T., Napitupulu, E.E., \& Hasratuddin, Peningkatan Kemampuan Berpikir Kritis Matematis Dan Kemandirian Belajar Siswa SMP Melalui Pembelajaran Berbasis Masalah. AdMathEdu, 5(1), 87106, 2015.

[9] Karami, M., Karami, Z., \& Attaran, M., Integrating Problem-Based Learning with ICT for Developing Trainee Teachers' Content Knowledge and Teaching Skill. International Journal of Education and Development Using Information and Communication Technology (IJEDICT), 9(1), 36-49, 2013.

[10] Lavasani, M.G., Mirhosseini, F.S., Hejazi, E., \& Davoodi, M. (2011). The Effect of Self-regulation Learning Strategies Training on the Academic Motivation and Self-efficacy. Procedia - Social and Behavioral Sciences (Published by Elsevier Ltd), 29 (2011) 627 - 632, 1877-0428.

[11] Marchis, I. (2011). How Mathematics Teachers Develop Their Pupils' Self-Regulated Learning Skills. Acta Didactica Napocensia, 4(2-3), 914.

[12] Minarni, A. (2017). On Eight Grade Students Understanding in Solving Mathematical Problems. Asian Social Science (Published by Canadian Center of Science and Education), 13(12), 86-96

[13] Minarni, A. \& Napitupulu, E.E. (2017). Developing Instruction Materials Based on Joyful PBL to Improve Students Mathematical Representation Ability. International Education Studies, 10(9), 23-38.

[14] Montalvo, F.T. \& Torres, M.C. (2004). Self-Regulated Learning: Current and Future Directions. Electronic Journal of Research in Educational Psychology, 2(1), 1-34.

[15] Panadero, E. \& Tapia, J.A. (2014). How Do Students Self-regulate? Review of Zimmerman's Cyclical Model of Self-regulated Learning. Anales De Psicologia, 30(2), 450-462.

[16] Parrot, M.A.S. \& Leong, K.E. (2018). Impact of Using Graphing Calculator in Problem Solving. Internasional Electronic Journal of Mathematics Education, 13(3), 139-148.

[17] Peranginangin, S.A., Saragih, S., \& Siagian, P. (2019). Development of Learning Materials Through PBL with Karo Culture Context to Improve Students' Problem Solving Ability and Self-efficacy. Internasional Electronic Journal of Mathematics Education, 14(2), 265-274. 
[18] Polya, G.( 1973). How To Solve It. New Jersey: Princeton University Press.

[19] Putri, S.K., Hasratuddin \& Syahputra, E. (2019). Development of Learning Devices Based on Realistic Mathematics Education to Improve Students' Spatial Ability and Motivation. Internasional Electronic Journal of Mathematics Education, 14(2), 393-400.

[20] Radhy, Z.H., Application of Multiply Regression Linear Model and New Technology Method in Estimating Learning and Education of Students. Internasional Electronic Journal of Mathematics Education, 14(1), 8790, 2019.

[21] Rohaeti, E.E., Bernard, M. \& Primandhika, R.B., Developing Interactive Learning Media For School Level Mathematics Through Open-Ended Approach Aided By Visual Basic Application For Excel. Journal on Mathematics Education, 10(1), 59-68, 2019.

[22] Rusyda, N.A. \& Sari, D.S., Pengaruh Penerapan Model Contextua Teaching And Learning Terhadap Kemampuan Pemahaman Konsep Matematis Siswa SMP Pada Materi Garis Dan Sudut. JNPM (Jurnal Nasional Pendidikan Matematika), 1(1), 150-162, 2017.

[23] Saha, R.A, Ahmad, F.M.A \& Rohani, A.T. The Effects of GeoGebra on Mathematics Achievement: Enlightening Coordinate Geometry Learning. Procedia Social and Behavioral Sciences 8 (2010) 686-693, 1877-0428.

[24] Schunk, D. H., Self-regulated Learning: The Educational Legacy of Paul R. Pintrich. Educational Psychologist, 40, 85-94, 2015

[25] Siagian, M.V., Saragih, S. \& Sinaga, B, Development of Learning Materials Oriented on Problem-Based Learning Model to Improve Students' Mathematical Problem Solving Ability and Metacognition Ability. Internasional Electronic Journal of Mathematics Education, 14(2), 331-340, 2019

[26] Simamora, R.E., Saragih, S., \& Hasratuddin, Improving Students' Mathematical Problem Solving Ability and Self-Efficacy through
Guided Discovery Learning in Local Culture Context. Internasional Electronic Journal of Mathematics Education, 14(1), 61-72, 2019.

[27] Simbolon, M., Mulyono, Surya, E. \& Syahputra, E., The Efforts to Improving the Mathematical Critical Thinking Student's Ability through Problem Solving Learning Strategy by Using Macromedia Flash. American Journal of Educational Research, 5(7), 725-731, 2017.

[28] Suarsana, I.M., Lestari, I.A.P.D, \& Mertasari, N.M. The Effect of Online Problem Posing on Students' Problem-Solving Abilitiy in Mathematics. International journal of instruction, 12(1), 809-820, 2019.

[29] Surya, E., Sabandar, J., Kusumah, Y.S., \& Darhim Improving of Junior High School Visual Thinking Representation Ability in Mathematical Problem Solving by CTL. IndoMS. J.M.E, 4(1), 113-126, 2013.

[30] Tambunan, H, The Effectiveness of the Problem Solving Strategy and the Scientific Approach to Students' Mathematical Capabilities in High Order Thinking Skills. Internasional Electronic Journal of Mathematics Education, 14(2), 293-302, 2019.

[31] Tambychik, T. \& Meerah, T.S.M. Students' Difficulties in Mathematics Problem-Solving: What do they Say?. Procedia Social and Behavioral Sciences (Published by Elsevier Ltd) 8 (2010), 142-151, 2010.

[32] Trianto, Mendesain Model Pembelajaran Inovatif Progresif. Jakarta: Kencana Prenada Media Group, 2009.

[33] Ulandari, L., Amry, Z. \& Saragih, S, Development of Learning Materials Based on Realistic Mathematics Education Approach to Improve Students' Mathematical Problem Solving Ability and Selfefficacy. Internasional Electronic Journal of Mathematics Education, 14(2), 375-383, 2019.

[34] Yanti, Peningkatan Kemampuan Pemecahan Masalah, Komunikasi Dan Konsep Diri Matematik Siswa SMP Melalui Pembelajaran Kontekstual Berbantuan Geogebra. Jurnal Penelitian Pendidikan, 16(2), 2541-4135. 2016.

[35] Zimmerman, B.J, Becoming Self-Regulated Learning: An Overview. Theory Into Practise, 41(2), 64-70, 2002. 